
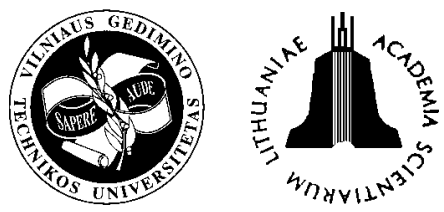

\title{
QUALITATIVE ANALYSIS OF THE KNOWLEDGE OF APPLICANTS TO TRANSPORT ENGINEERING COURSES OF STUDY
}

\author{
Romualdas Kliukas ${ }^{1}$, Olegas Prentkovskis ${ }^{2}$, Alfonsas Daniūnas ${ }^{3}$ \\ Vilnius Gediminas Technical University, Admission Commission, \\ ${ }^{1}$ Sauletekio al. 11, LT-10223 Vilnius, Lithuania, Phone +370 5 274 5010,E-mail: pirmininkas@adm.vtu.lt \\ 2 Plytinès g. 27, LT-10105 Vilnius, Lithuania, Phone +370 5274 4784,E-mail: olegas@ti.vtu.lt \\ ${ }^{3}$ Sauletekio al. 11, LT-10223 Vilnius, Lithuania, Phone +370 5274 5003, \\ E-mail:alfonsas.daniunas@adm.vtu.lt
}

Received 10 November 2005, accepted 28 March 2006

\begin{abstract}
The problems of selecting applicants to the Lithuanian universities and the level of knowledge of the applicants to transport engineering specialities will be discussed in this paper. A brief analysis of courses of studies in transport engineering at theLithuanian univitersities is presented. Some statistical data reflecting the results of joint applicants admission to the Lithuanian higher schools are presented. The selection of applicants to study transport engineering courses at the Lithuanian universities is analyzed.
\end{abstract}

Keywords: the Lithuanian universities, applicants, transport engineering courses of studies, admission, qualitative evaluation.

\section{Introduction}

When Lithuania joined the European Union, transport became one of the most important branches of national economy. Now, the economic development is hardly possible without an effective transport system (providing both national and international transportation). The operation of industrial construction and agricultural enterprises as well as work efficiency and public opinion largely depend on reliability and effective performance of transport [1-9].

The main goals of transport development are: the increase of volume of transportation and the improvement of quality of transport services ensuring safe traffic and transportation of goods and passengers [1-9]. To solve these problems, a comprehensive approach, taking into account the capacities of all parts of transport system, should be used. However, the emphasis should be placed on a human factor [10].

Effective transport management ensuring traffic safety requires that a specialist in transport engineering (a university graduate) should have profound and versatile knowledge in various subjects, i.e. automobile engineering, road construction, transport management, applied mathematics, automatic control systems, etc.

The Lithuanian universities train qualified specialists in transport engineering who are highly appraised in the European Union.
However, employers would like to employ specialists having more practical skills in using advanced technologies and business strategies. These skills can be developed when graduates have worked several years at an enterprise. Moreover, to become a highly qualified specialist, good speciality knowledge acquired at the university, fundamental knowledge of transport engineer's work and friendly environment at an enterprise are required.

Such specialists can be trained only when close cooperation is established between universities and transport enterprises.

Professional guidance of secondary school 16-18 year-old children by informing them of the specific character of various jobs, motivation for choosing a particular speciality, preparation and selection of school-leavers for universities make the first step in providing the labour market with qualified and initiative specialists.

For many years now researchers and university teachers have been studying various problems of higher education associated with [11-20]:

- engineering education;

- $\quad$ new trends in teaching strategies;

- internationalization of university studies on various levels;

- the development of higher education; 
- continuous university education;

- $\quad$ selection of applicants to higher and other types of schools;

- $\quad$ selection of university graduates for qualified jobs at various enterprises.

The problems of selecting applicants to the Lithuanian universities and the level of knowledge of the applicants to transport engineering specialities will be discussed further.

\section{A brief description of the Lithuanian universities and the selection of students}

Sixteen university-level higher schools are officially registered in Lithuania [21, 22]. They are as follows:

- General Jonas Žemaitis Military Academy of Lithuania;

- Kaunas University of Medicine;

- Kaunas University of Technology;

- Klaipèda University;

- Lithuanian Academy of Physical Education;

- Lithuanian Academy of Music and Theatre;

- Lithuanian Veterinary Academy;

- Lithuanian University of Agriculture;

- Mykolas Romeris University;

- $\quad$ Siauliai University;

- Vilnius Academy of Fine Arts;

- Vilnius Gediminas Technical University;

- Vilnius Pedagogical University;

- Vilnius University;

- Vytautas Magnus University;

- University of Management and Economics. The above higher schools formed an Association of Lithuanian higher schools to implement the programme of joint admission helping the applicants to enter a higher school and to reduce the risk of a single possible choice, as well as making the selection of potential students more objective and simplifying the entrance by allowing them to apply to several higher schools simultaneously. Based on this programme, an applicant is given an opportunity to choose a higher school and a course of studies according to his/her order of preference and depending on the marks obtained in a secondary school. An applicant submits an application to any of the higher schools of the Association allowing him/her to select a number of courses in several higher schools.

In 2005, the Lithuanian higher schools participating in joint applicants admission programme offered the applicants over 740 courses of studies in six fields of science registered in Lithuania, such as technological, social, physical and biomedicine sciences, humanities and fine arts [21-23].

Three of the above-mentioned higher schools offer courses of studies in transport engineering leading to Bachelor's degree in transport engineering [2127]. They are as follows:

- Vilnius Gediminas Technical University;

- Kaunas University of Technology;

- Klaipéda University.

Fig 1 presents a map of Lithuania showing the location of these universities and the available courses of studies in transport engineering belonging to the field of technological sciences.

Much more students were admitted to full-time studies of transport engineering than to part-time studies and distant learning programme. Further, the data on the selection of applicants to full-time studies are analysed.

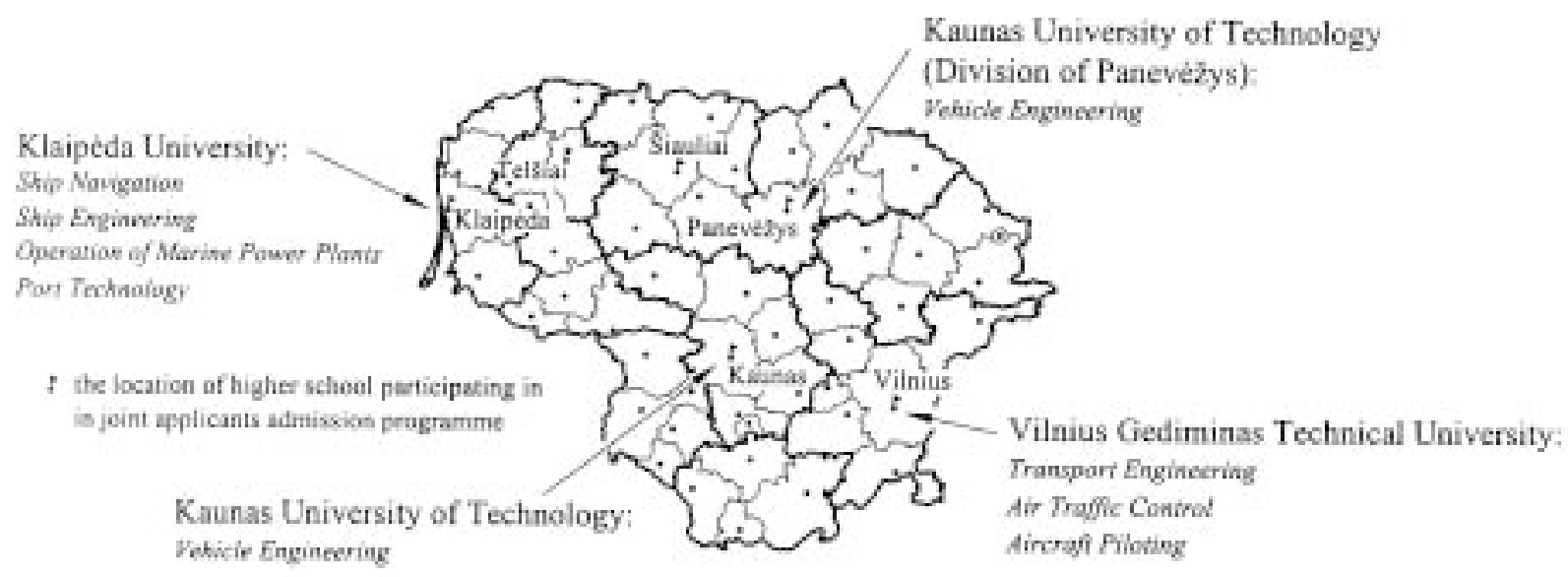

Fig 1. A map of Lithuania showing the location of universities providing courses of studies in transport engineering 


\section{A brief analysis of courses of studies in transport engineering}

\subsection{Courses of studies available at Vilnius Gediminas Technical University}

Three full-time courses of studies in the area of transport engineering are available at Vilnius Gediminas Technical University [21, 22, 24, 25]. They are Transport Engineering (with specializations in Automobile Transport Engineering, Railway Transport Engineering, Transport Technological Systems Engineering), Aircraft Traffic Control and Aircraft Piloting.

The course of studies in Transport Engineering at Vilniaus Gediminas Technical University deals with maintenance of vehicles, focussing on fundamental theoretical problems of vehicle design and maintenance, including traffic safety, diagnostics, technological equipment, maintenance materials, as well as economic, legislative and work organization problems.

Graduates can get jobs at transport enterprises, car service stations, car sales and insurance companies, motor licensing and traffic police departments, state inspection stations, drivers' schools and other transport-related enterprises as well as in the company "Lithuanian Railways" and at industrial enterprises related to railway transport as specialists of transport facilities maintenance. They can also be employed in automobile road administration board, fire prevention and rescue services, at customs departments, airports, logistics centres, transport terminals and filling stations.

When Lithuania regained independence, the efforts were made to rebuild and develop a national aircraft system, trying to integrate it into the European and worldwide aviation systems. To achieve this, aircraft specialists satisfying international requirements are needed.

The graduates from Aircraft Piloting can get jobs at the companies "FlyLAL", "Air Lithuania", in Lithuanian Air orces, at the Flight Department of the Ministry of Interior, etc.

On completing the course of Air Traffic Control graduates are qualified as heads of flights, controlling flights over the airport and on various airlines with or without radar equipment. They can get jobs at the departments of the state enterprise "Air navigation" in Vilnius, Kaunas, Klaipèda and Šiauliai and at the flight safety departments as well as in the Air Force Control centre of the Baltic region.

\subsection{Courses of studies available at Kaunas Uni-} versity of Technology

One full-time course of studies in the area of transport engineering is available at Kaunas University of Technology [23, 24, 26], i.e. Vehicle Engineering (with specializations in Aviation Engineering, Engineering and Management of Railway Transport, Engineering of Railway Transport Means, Engineering of Road Transport Means).

Students taking this course study the fundamentals of operation, design and manufacture of vehicles as well as the use of advanced materials and technologies, in addition to fundamental sciences.

Highly qualified specialists for maintenance and use of a modern road, air and railway transport are trained at Kaunas University of Technology.

On completing the course, graduates can work at transport maintenance and repair enterprises. They can also be employed by companies selling and servicing the equipment of vehicles, roads and transport terminals and participate in equipment and vehicle adaptation projects.

\subsection{Courses of studies available at Klaipèda University}

Three full-time courses of studies in the area of transport engineering are available at Klaipeda University [23, 24, 27]. They are: Ship Engineering, Port Technology, Ship Navigation and Operation of Marine Power Plants.

A course of studies in Ship Engineering includes hydroaeromechanics, structural mechanics of ships, ship body structure, shipping theory, ship systems and equipment, ship design, building, repair, management and maintenance in addition to fundamental sciences.

A course of Port Technology includes shipping theory and ship-building, steering, navigation, operation of marine power plants, port and water way geography, mechanization and automation of ports, sea transport steering, port terminals, shipping of goods and ship and goods forwarding. On completing the courses, graduates can work as port administrators, as well as being employed by safe shipping administration, goods shipping companies, ship and goods forwarding firms, surveillance and other sea transport companies.

A course of Ship Navigation is aimed at ship pilot training. Such subjects as shipping theory and ship building, navigation equipment, steering of marine vessels, sea fishery, ship's crew training, shipping technologies and marine power plants. Graduates are awarded a Bachelor's degree in transport engineering as well as getting engineer-ship pilot qualification. On completing the courses graduates can work as ship pilots at various enterprises and companies providing sea transport services as well as making research, teaching, design, manufacture, business, etc. in the above field.

A course of Operation of Marine Power Plants includes such subjects as internal combustion of steam and turbine engines and power plants on board the 
ship, as well as diagnostics and repair of ships and their equipment and electrical machines and their maintenance. Graduates get a Bachelor's degree in transport engineering and the qualification of engineer-marine vessel mechanic.

\section{Employment prospects for graduates}

As shown by the survey conducted by the Institute of Labour and Social Research (Table 1) [21, 22], the graduates from Vilnius Gediminas Technical University $(82,8 \%)$ and Kaunas University of Technology $(80 \%)$ have the best opportunities for getting a job. The graduates from Vilnius University and Šiauliai University also have good chances to find a job. Researchers have emphasized that the graduates of higher technical schools have better chances for getting a job than the graduates from Vilnius University, explaining it by the bias of the latter towards the humanities. However, the graduates with technological qualification are in a higher demand on the labour market.

Basing on the above survey, it may be concluded that the qualification of graduates is more important in getting a job than the type and prestige of a higher school. The graduates who studied technological or physical sciences have the best chances for getting employment $(85,1 \%)$. The lower demand is for specialists in the humanities $(64,9 \%)$ and social sciences $(75,3 \%)[21,22]$.

\section{Some statistical data reflecting the results of joint applicants admission to the Lithuanian higher schools}

In Lithuania, school-leavers can take state or school examinations on different levels $(T, A$ or $B)$ [21, 23, 25-28].

For each applicant to a higher school, a competitive mark obtained as the total product of the school marks for particular subjects and the weighted coefficient are calculated.

Each higher school uses a specific method of calculating competitive marks [23, 25-27]. All the marks taken from a school-leaving certificate which are required for a person to be admitted are recalculated according to a commonly used system [21, 23, 25-28].

An applicant can mention about twenty courses of studies in his/her application [21]. An average number of courses chosen by school-leavers has been constant for some years (Fig 2) and makes about 10 issues [29].

The popularity of various sciences with schoolleavers varies to a large extent (Fig 3) [29]. A prestige of technological sciences is demonstrated in Fig 4 [29].

About $36 \%$ of the total number of 35916 appli-
Table 1. Rating of higher schools according to the level of graduates' employment

\begin{tabular}{|c|c|c|c|c|}
\hline Rank & $\begin{array}{l}\text { Higher } \\
\text { school }\end{array}$ & Employed, & $\begin{array}{c}\text { Employed } \\
\text { according to } \\
\text { the acquired } \\
\text { qualification, } \\
\%\end{array}$ & $\begin{array}{c}\text { Satisfied } \\
\text { with } \\
\text { payment, } \\
\%\end{array}$ \\
\hline 1 & $\begin{array}{l}\text { Vilnius } \\
\text { Gediminas } \\
\text { Technical } \\
\text { University }\end{array}$ & 82,8 & 63,8 & 40,1 \\
\hline 2 & $\begin{array}{l}\text { Kaunas } \\
\text { University of } \\
\text { Technology }\end{array}$ & 80,0 & 73,2 & 43,9 \\
\hline 3 & $\begin{array}{l}\text { Vilnius } \\
\text { University }\end{array}$ & 77,6 & 67,1 & 46,1 \\
\hline 4 & $\begin{array}{l}\text { Šiauliai } \\
\text { University }\end{array}$ & 77,5 & 81,1 & 56,8 \\
\hline 5 & $\begin{array}{l}\text { Utena } \\
\text { College }\end{array}$ & 75,0 & 53,3 & 33,3 \\
\hline 6 & $\begin{array}{l}\text { Klaipėda } \\
\text { University }\end{array}$ & 73,5 & 69,7 & 40,3 \\
\hline 7 & $\begin{array}{l}\text { International } \\
\text { Business } \\
\text { School at } \\
\text { Vilnius } \\
\text { University }\end{array}$ & 72,2 & 69,0 & 57,6 \\
\hline 8 & $\begin{array}{l}\text { Vilnius } \\
\text { Pedagogical } \\
\text { University }\end{array}$ & 71,6 & 68,6 & 29,2 \\
\hline 9 & $\begin{array}{l}\text { Vilnius } \\
\text { College }\end{array}$ & 69,0 & 52,4 & 38,1 \\
\hline 10 & $\begin{array}{l}\text { Alytus } \\
\text { College }\end{array}$ & 65,5 & 52,6 & 36.8 \\
\hline 11 & $\begin{array}{l}\text { Vilnius Co- } \\
\text { operative } \\
\text { College }\end{array}$ & 63,6 & 33,3 & 53.3 \\
\hline 12 & $\begin{array}{l}\text { Lithuanian } \\
\text { University of } \\
\text { Agriculture }\end{array}$ & 61,7 & 54,0 & 45,1 \\
\hline 13 & $\begin{array}{l}\text { Kaunas } \\
\text { College }\end{array}$ & 60,0 & 83,3 & 75,0 \\
\hline 14 & $\begin{array}{l}\text { Lithuanian } \\
\text { Academy of } \\
\text { Physical } \\
\text { Education }\end{array}$ & 60,0 & 57,9 & 47,4 \\
\hline 15 & $\begin{array}{l}\text { Vytautas } \\
\text { Magnus } \\
\text { University }\end{array}$ & 59,7 & 70,2 & 45,0 \\
\hline
\end{tabular}

cants to the Lithuanian higher schools in 2005 mentioned one course of study in a particular field, $37 \%-$ two and $21 \%$ - three courses of studies in their applications for enrolment into a higher school. This shows that now applicants have strong motivation for choosing specialities.

However, the choice of popular courses of studies in particular fields (see Fig 3) does not match the 
demands of the labour market and higher school capabilities. According to the data provided by the Labour Exchange, specialists in the fields of technological and physical sciences are in great demand [21, $22]$. Therefore, the popularity of courses of studies in particular fields does not conform either with statefixed high school quotas or market demands.

The distribution of the state-fixed quotas of students for higher schools among various fields of science is shown in Fig 5 [29].

Social sciences make the most popular field (Fig 3). About $60 \%$ of applicants would like to study these sciences, however, the state-fixed quota for this field makes $38,7 \%$ of the total number of the applicants (Fig 5). This amounts to 21600 and 9500 of the

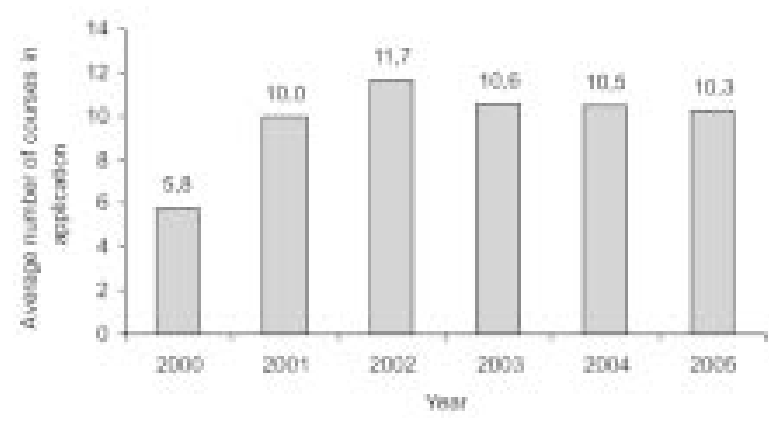

Fig 2. Average number of selected courses mentioned in school-leaver's application
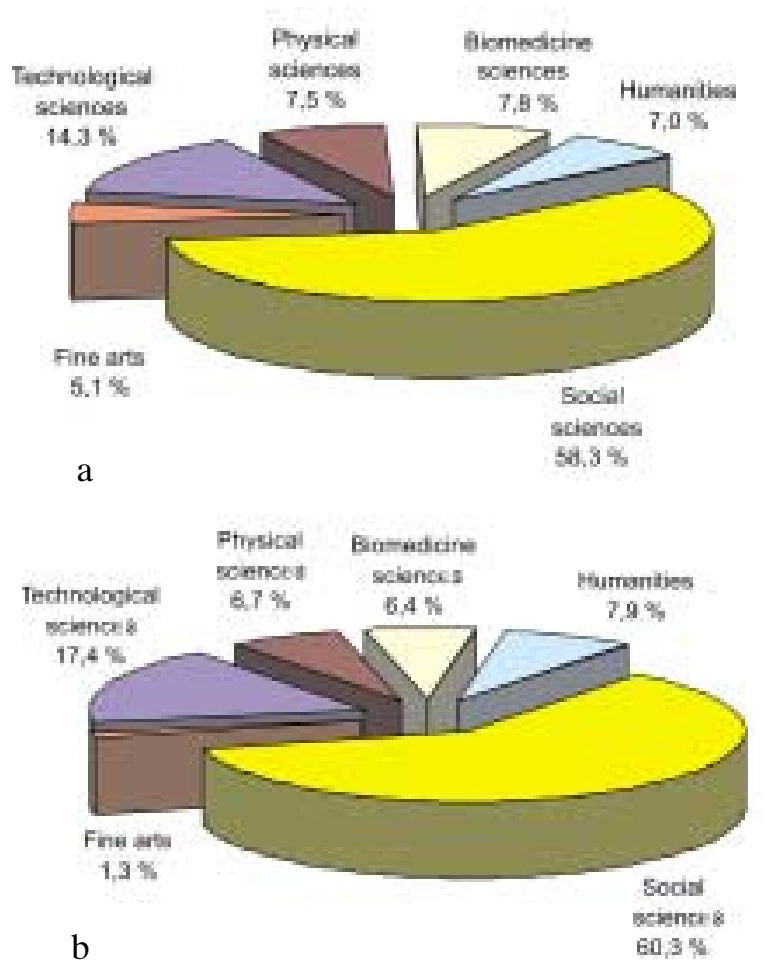

Fig 3. Popularity of courses of studies according to the fields of sciences mentioned in school-leaver's applications in 2005: a - based on course No 1 in the application; $\mathrm{b}$ - based on all courses mentioned in the application

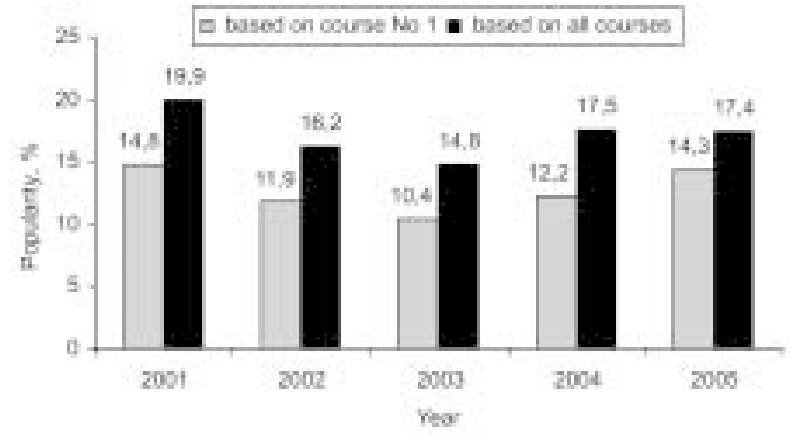

Fig 4. Popularity of a course of studies in technological sciences, in per cent (the number of applicants to all courses of studies is assumed to be equal to $100 \%$ )

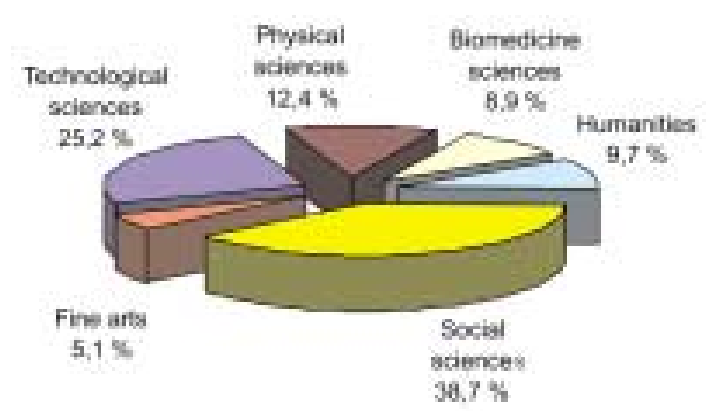

Fig 5. Distribution of state-fixed quotas of students at higher schools in 2005 according to the fields of science

applicants, respectively. Hence, less than a half of the applicants (the best ones) are admitted to take the courses of studies in social sciences, while others can take courses in other fields of science.

About 5000 applicants would like to study technological sciences, however, 6200 school-leavers are admitted to the Lithuanian universities to take these courses. The popularity of the field of technological sciences makes about $15 \%$ and it has been relatively stable, varying only to some extent, depending on the employment rate in the field and the changing views of the society (the popularity ranges from 10,4\% to $14,8 \%$ if ranked the first in the school-leaver's application, and from $14,8 \%$ to $19,9 \%$ based on the total number of choices (see Figs 3, 4)).

The most popular courses of studies in the field of technological sciences based on the first order of the applicants' preference are presented in Table 2 [29].

As shown in the table, the most popular courses of studies in the field of technological sciences remain Civil Engineering and Transport Engineering.

The following abbreviations are used in the figures and tables given below: VGTU - Vilnius Gediminas Technical University; KUT - Kaunas University of Technology; KUT DP - Kaunas University of Technology (Division of Panevěžys); KU - Klaipėda University.

The popularity of full-time studies of various 
Table 2. The most popular courses of studies in technological sciences based on the courses ranked the first in the application

\begin{tabular}{|l|c|c|}
\hline \multicolumn{1}{|c|}{ Course of studies } & University & Popularity \\
\hline Civil Engineering & VGTU & 494 \\
\hline Civil Engineering & KUT & 272 \\
\hline Transport Engineering & VGTU & 184 \\
\hline Informatics Engineering & KUT & 170 \\
\hline $\begin{array}{l}\text { Telecommunications and } \\
\text { Electronics }\end{array}$ & KUT & 130 \\
\hline $\begin{array}{l}\text { Information Systems } \\
\text { Engineering }\end{array}$ & VGTU & 130 \\
\hline Civil Engineering & KU & 113 \\
\hline $\begin{array}{l}\text { Telecommunications } \\
\text { Engineering }\end{array}$ & VGTU & 110 \\
\hline Environmental Engineering & VGTU & 108 \\
\hline
\end{tabular}

transport engineering courses based on the first order and all orders of preference is shown in Fig 6. An applicant could mention up to 20 courses of studies in his/her application. At the top of the column the number of applicants who have chosen the above-mentioned course of studies marking it No 1 (Fig 6 a) and by any other number (Fig 6 b) is given.

The considered courses of studies in transport engineering are mostly chosen by males. They made $90,04 \%$ in VGTU, 90,24\% in KU and 95,15\% in KUT (together with KUT DP).

\section{Analysis of the selection of applicants to study trans- port engineering courses}

427 applicants were admitted to take courses in transport engineering at the Lithuanian universities in 2005 (Fig 7) [29].

The applicants to VGTU and KU had the best competitive marks. For example, all applicants admitted to VGTU to study the courses of studies in Transport Engineering passed the state examination in mathematics and $45 \%$ of the total amount got 50 points. As shown by the above data, VGTU and KU courses of studies in transport engineering are more popular.

This may be for the following reasons:

- Vilnius and Klaipeda are two largest cities of Lithuania where a large number of transport enterprises are located and the demand for qualified specialists in this area is great;

- Vilnius as the capital of Lithuania attracts investments and has a great number of industrial and construction enterprises, as well as logistics centres;

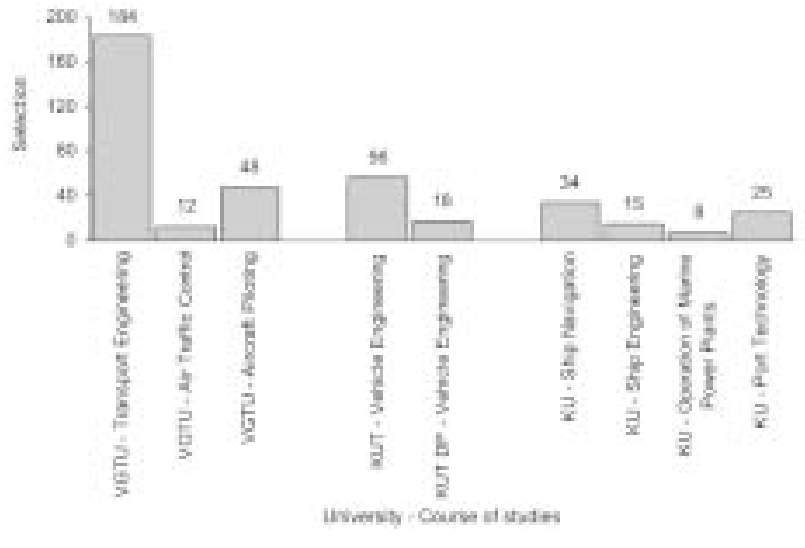

a

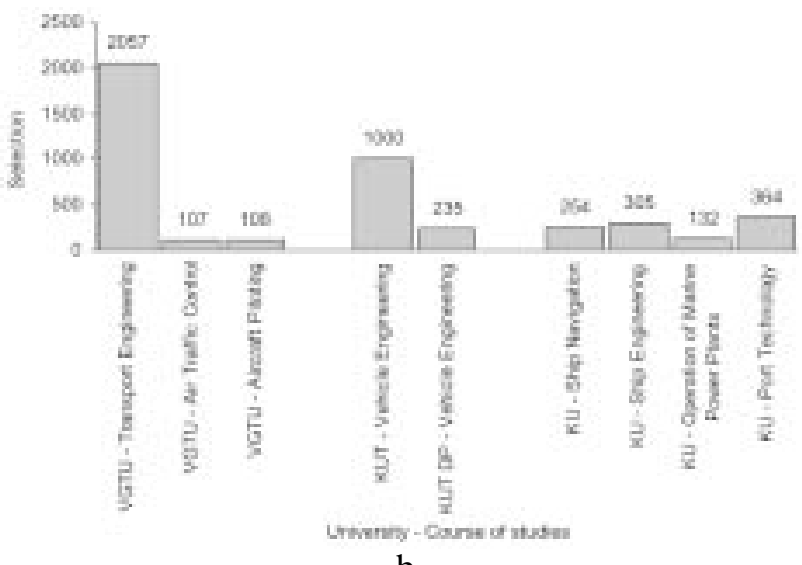

b

Fig 6. Popularity of courses of full-time studies in transport engineering (in units) in 2005 based on: a - the first order of preference in the application; $b$ - all orders of preference

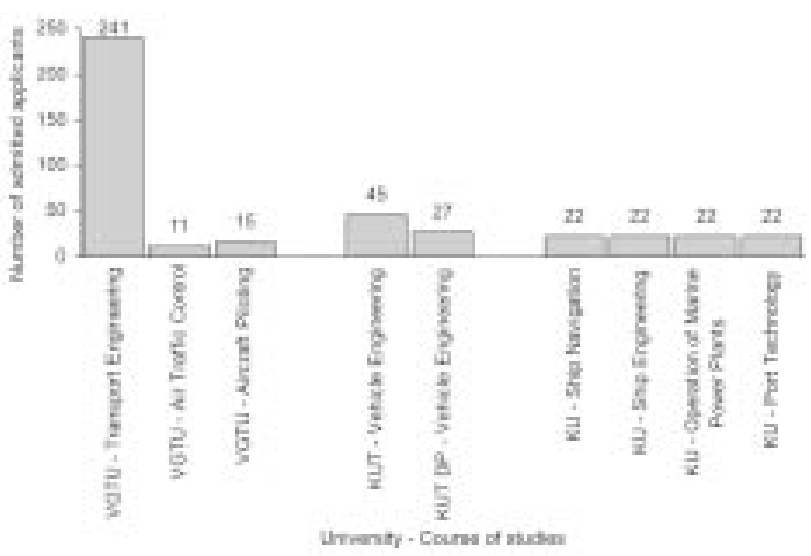

Fig 7. The number of applicants admitted to study full-time transport engineering courses in 2005

- Klaipeda port is short of specialists in transport engineering;

- Vilnius has long-established traditions in training transport engineers;

- A course of transport engineering at Kaunas University of Technology is mainly oriented to machine building, while this course at Vilnius Gediminas Technical University and Klaipeda 
University centres on transport facility maintenance.

The statistical data given below illustrate the preparation of the applicants for studying rather difficult engineering sciences. One can see that their level is sufficiently high (Figs 8, 9) [29].

Competitive marks [21, 25-27] of the applicants to transport engineering courses at various universities are given in Table 3, while the highest marks (without any additional points) are presented in Table 4.

The highest competitive marks are calculated, taking into account that the marks for the subjects in the applicant's school-leaving certificate taken for calculating the competitive marks are the highest (any additional points given to a school-leaver for other activities are not considered).

The relationships between the lowest and the highest competitive marks of all applicants admitted to full-time studies in transport engineering courses and the highest possible marks are given in Fig 8. The highest value of the relationship would be equal to unity.

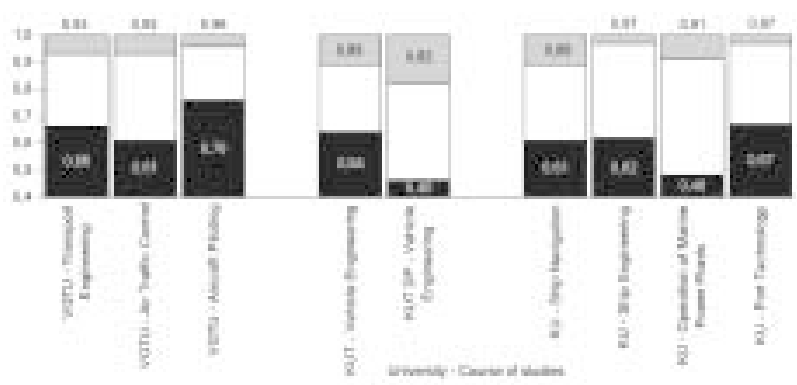

Fig 8. The relationship between the lowest (the upper limit of a black shaded area) and the highest (the lower limit of a grey shaded area) competitive marks and the highest possible marks for taking the full-time studies in transport engineering courses in 2005

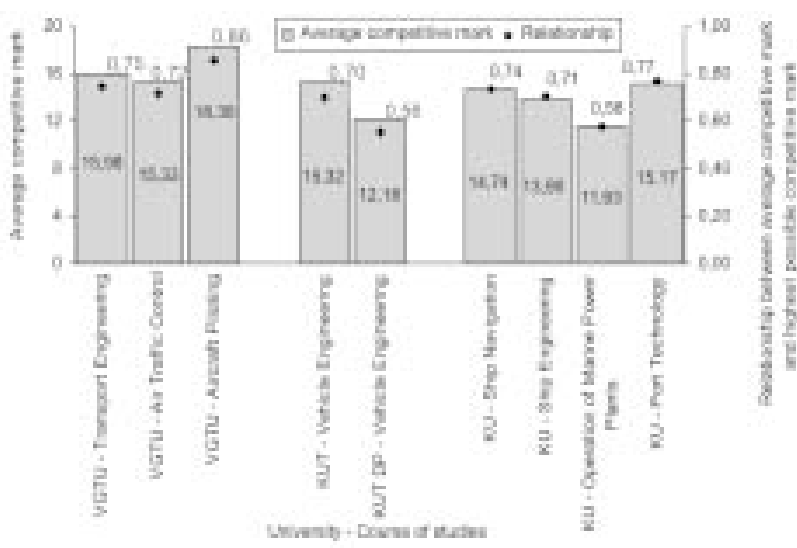

Fig 9. Average competitive marks of the admitted applicants and their relationship with the highest possible competitive mark for taking transport engineering courses in 2005
Table 3. Competitive marks of applicants to transport engineering courses of studies at various universities

\begin{tabular}{|l|c|l|c|}
\hline $\begin{array}{c}\text { Examination } \\
\text { mark at } \\
\text { school }\end{array}$ & $\begin{array}{c}\text { Weighted } \\
\text { coefficient }\end{array}$ & $\begin{array}{c}\text { A yearly mark in } \\
\text { school-leaving } \\
\text { certificate }\end{array}$ & $\begin{array}{c}\text { Weighted } \\
\text { coefficient }\end{array}$ \\
\hline $\begin{array}{l}\text { Vilnius Gediminas Technical University: } \\
\text { Transport Engineering } \\
\text { Air Traffic Control } \\
\text { Aircraft Piloting }\end{array}$ & \multirow{2}{*}{$\begin{array}{l}\text { a foreign } \\
\text { language or } \\
\text { physics }\end{array}$} & 0,15 \\
\hline mathematics & 0,50 & \\
\hline $\begin{array}{l}\text { the } \\
\text { Lithuanian } \\
\text { language } \\
\text { (test) }\end{array}$ & 0,20 & \\
\cline { 1 - 2 } $\begin{array}{l}\text { physics or a } \\
\text { foreign } \\
\text { language }\end{array}$ & 0,15 & & \\
\hline
\end{tabular}

Kaunas University of Technology and

Kaunas University of Technology

(Division of Panevėžys):

Vehicle Engineering

\begin{tabular}{|l|c|l|l|}
\hline mathematics & 0,50 & & \\
\hline $\begin{array}{l}\text { the } \\
\text { Lithuanian } \\
\text { language } \\
\text { (test) }\end{array}$ & 0,20 & & \\
\hline physics & 0,20 & & \\
\hline $\begin{array}{l}\text { a foreign } \\
\text { language }\end{array}$ & 0,10 & & \\
\hline
\end{tabular}

Klaipėda University:

Ship Engineering

Port Technology

\begin{tabular}{|l|c|l|c|}
\hline mathematics & 0,38 & mathematics & 0,17 \\
\hline $\begin{array}{l}\text { physics or } \\
\text { information } \\
\text { technologies }\end{array}$ & 0,25 & $\begin{array}{l}\text { physics or } \\
\text { information } \\
\text { technologies }\end{array}$ & 0,10 \\
\hline $\begin{array}{l}\text { a foreign } \\
\text { language }\end{array}$ & 0,06 & $\begin{array}{l}\text { a foreign } \\
\text { language }\end{array}$ & 0,04 \\
\hline
\end{tabular}

Klaipėda University:

Ship Navigation

Operation of Marine Power Plants

\begin{tabular}{|l|c|l|c|}
\hline mathematics & 0,33 & mathematics & 0,12 \\
\hline physics & 0,25 & physics & 0,10 \\
\hline $\begin{array}{l}\text { a foreign } \\
\text { language }\end{array}$ & 0,15 & $\begin{array}{l}\text { a foreign } \\
\text { language }\end{array}$ & 0,05 \\
\hline
\end{tabular}

The relationships between the average competitive marks of all admitted applicants to full-time studies in transport engineering courses and the highest possible mark are presented in Fig 9. The highest value of the relationship would be equal to unity.

The average competitive mark of all admitted to study a particular course is calculated as follows: 
Table 4. The highest competitive marks (without any additional points) of the applicants to transport engineering courses of studies at various universities

\begin{tabular}{|c|c|}
\hline Course of studies & $\begin{array}{c}\text { The highest competitive } \\
\text { mark }\end{array}$ \\
\hline \multicolumn{2}{|c|}{ Vilnius Gediminas Technical University } \\
\hline Transport Engineering & \multirow{3}{*}{21,35} \\
\hline Air Traffic Control & \\
\hline Aircraft Piloting & \\
\hline \multicolumn{2}{|c|}{$\begin{array}{l}\text { Kaunas University of Technology and } \\
\text { Kaunas University of Technology (Division of Panevėžys) }\end{array}$} \\
\hline Vehicle Engineering & 21,90 \\
\hline \multicolumn{2}{|l|}{ Klaipėda University } \\
\hline Ship Engineering & \multirow{2}{*}{19,59} \\
\hline Port Technology & \\
\hline Ship Navigation & \multirow[b]{2}{*}{20,03} \\
\hline $\begin{array}{l}\text { Operation of Marine Power } \\
\text { Plants }\end{array}$ & \\
\hline
\end{tabular}

$$
K_{\text {aver }}=\frac{\sum_{i=1}^{m} K_{i}}{m},
$$

where $K_{\text {aver }}$ is an average competitive mark; $K_{i}$ is a competitive mark of the $i$-th admitted applicant; $m$ is the number of admitted to study a course.

The competitive marks of the first group of the admitted school-leavers (Fig 8) range from 89 to $97 \%$ compared to the highest possible mark, while the marks of the last group of the admitted range from 60 to $78 \%$, which are relatively high competitive marks for the applicants to study technological sciences.

The average competitive marks of the admitted to full-time studies in transport engineering courses are very high (except for the courses of Vehicle Engineering in KUT DP and Operation of Marine Power Plants in KU). They range from 70 to $86 \%$ compared to the highest possible competitive mark (Fig 9).

The analysis of the statistical data reflecting the preparation of the admitted to transport engineering courses of studies allows us to believe that over 400 first-year students (Fig 7) will graduate from a university with a Bachelor's degree and continue their studies for a Master's degree.

The competitiveness index shows the preparation for studies and intellectual potential of the admitted to a particular course. It is calculated as the average mark of the key subjects in the school-leaving certificates of all admitted to study this course.

The competitiveness index of the admitted to study a particular course is calculated in the following way:

$$
I_{c}=\frac{\sum_{i=1}^{m}\left(\frac{L L+M+P+F L+H}{5}\right)_{i}}{m},
$$

where $I_{c}$ is competitiveness index of the admitted to a particular course of studies; $m$ is the number of the admitted to the course; $L L$ is a mark for the Lithuanian language in school-leaving certificate; $M$ is a mark for mathematics in school-leaving certificate; $P$ is a mark for physics in school-leaving certificate; $F L$ is a mark for a foreign language; $H$ is a mark for history in school-leaving certificate.

To calculate $I_{c}$, a mark obtained at the state examination is considered. If this exam was not taken, the mark obtained at school-leaving examination is considered. When this was not taken, then, the yearly mark in the school-leaving certificate is taken.

The competitiveness index shows the competitiveness of an applicant to study any course at a higher school (compared to other applicants).

The higher the competitiveness index of a course of studies, the higher the general level of education of a person admitted to a considered course.

As shown in Fig 10, the competitiveness indixes of full-time courses of studies in transport engineering are rather high, ranging from 27,22 to 49,90 in VGTU; from 18,61 to 40,03 in KU; and from 14,68 to 27,46 in KUT. However, they are considerably lower than the indixes for social sciences and relatively high for technological sciences. The highest possible competitiveness index for the best applicant is equal to 100 .

Training of a qualified specialist depends not only on the number of qualified university teachers, wellequipped laboratories and training centres, but also on the thirst for knowledge and eagerness of an applicant to become a qualified specialist in the selected field,

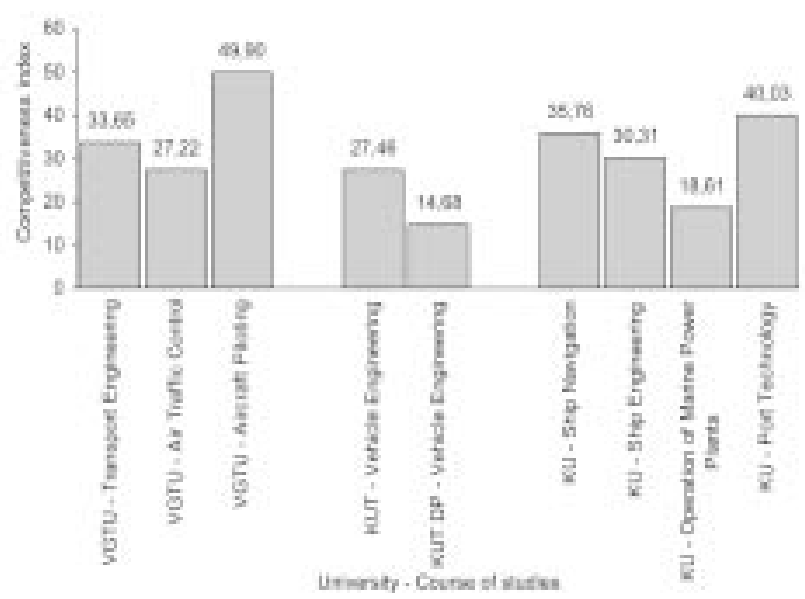

Fig 10. Competitiveness indexes of full-time studies in transport engineering courses in 2005 
i.e. his/her motivation. Motivation is reflected by the order of preference given by an applicant to a particular course of studies in the application to a university.

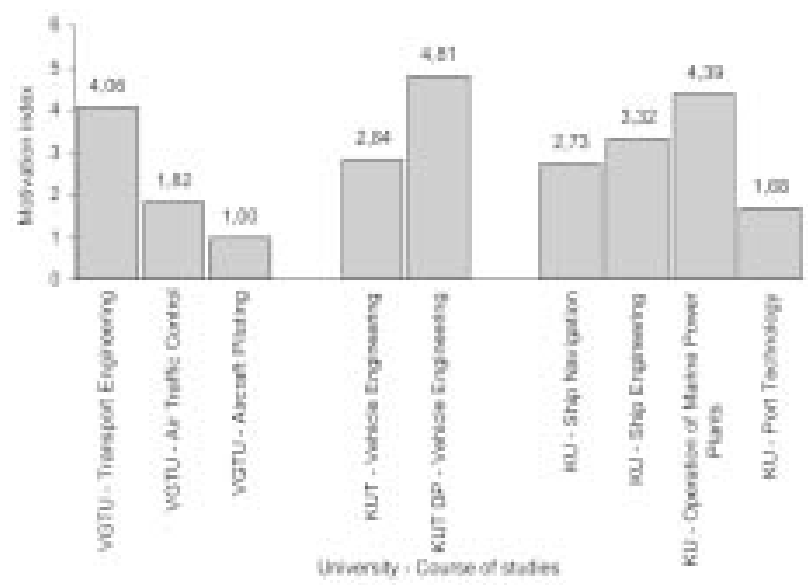

Fig 11. Motivation indexes of full-time studies in transport engineering courses in 2005
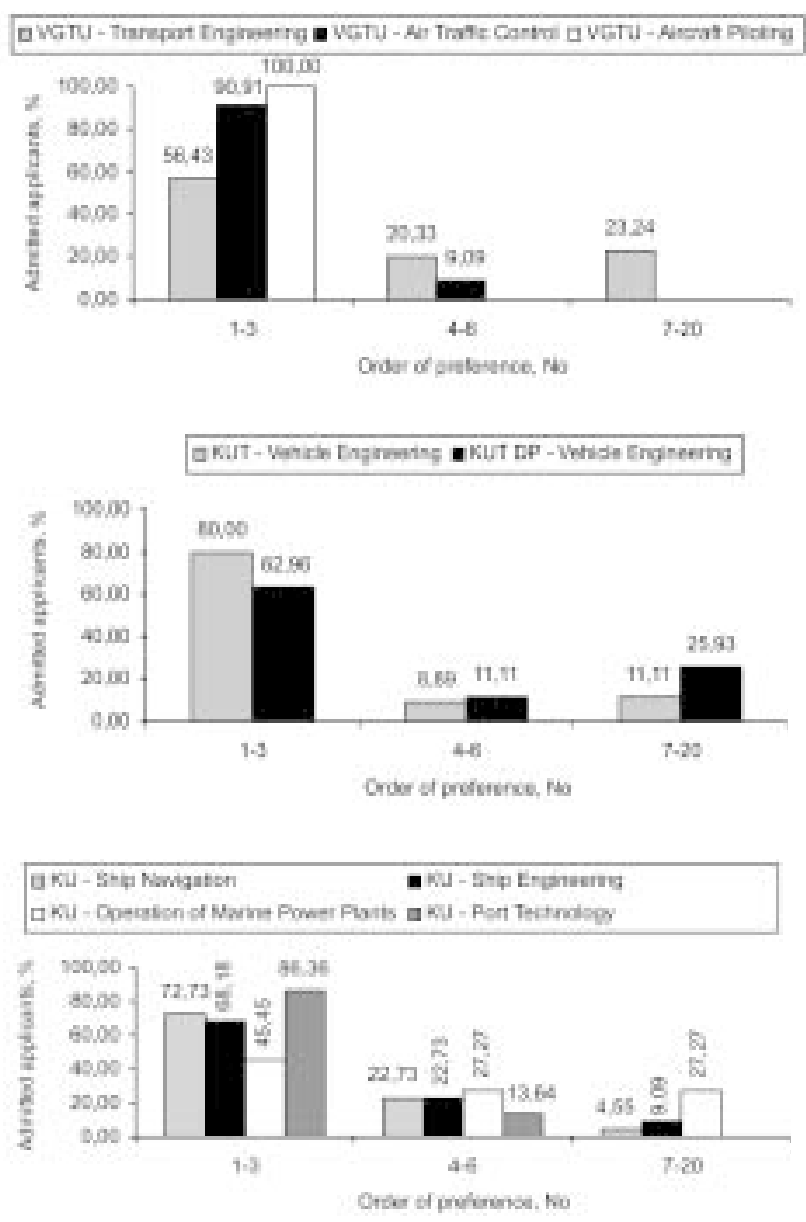

Fig 12. Distribution of the applicants admitted to study the courses in transport engineering according to the preference order of a course of studies in their applications
The motivation index is calculated by the formula:

$$
I_{m}=\frac{\sum_{i=1}^{m} O_{i}}{m},
$$

where $I_{m}$ is a motivation index of a particular course of studies; $O_{i}$ is the order of preference (No) given by the $i$-th applicant to a particular course of studies; $m$ is the number of young people admitted to a particular course of studies.

The lower the index value, the higher the motivation of young people taking a particular course of studies. The ideal motivation index is $I_{m}=1$, when all school-leavers admitted to a particular course of studies mention it in the application as choice No 1.

Motivation indexes of full-time studies in transport engineering courses are given in Fig 11.

As shown in Fig 11, the motivation index of VGTU Aircraft Piloting is equal to unity, $I_{m}=1$. Motivation indexes of other transport engineering courses are about 5, showing that well motivated applicants decided to study transport engineering courses.

This is also demonstrated by the distribution of young people admitted to study transport engineering courses depending on the preference order given to a particular course in their applications to a university (Fig 12).

\section{Conclusions}

1. The number of applicants admitted to study technological sciences is insufficient to satisfy the labour market demand and the capacities of universities.

2. Courses of studies in transport engineering are among the most popular in technological sciences.

3. The educational level of the applicants and those admitted to take various courses of studies in transport engineering is sufficiently high, which is certified by their competitive marks (Figs 8,9) and competitiveness indexes (Fig 10).

4. The applicants opting for the courses of studies in transport engineering are well motivated. This particularly applies to those admitted to Aircraft Piloting in Vilnius Gediminas Technical University, Port Technology in Klaipèda University and Air Traffic Control in Vilnius Gediminas Technical University. The motivation index of applicants to other courses of studies in transport engineering is also relatively high (about 4,81).

5. As shown by independent studies, the graduates completing the courses in technological sciences actually have no employment problems. Specialists of various fields of transport engineering have not been found in the lists of the unemployed registered at the National labour exchange. 


\section{References}

1. Baublys, A.; Bogdevičius, M.; Prentkovskis, O. et al. Transport: Technologies, Economics, Environment, Health: Monograph (Transportas: technologijos, ekonomika, aplinka, sveikata. Monografija). Vilnius: Technika, 2003. 876 p. (in Lithuanian).

2. Baublys, A; Palšaitis, R.; Lingaitis, L. P. et al. Science and Arts of Lithuania, Vol 22. Transport: monograph (Lietuvos mokslas, 22 knyga. Transportas: monografija). Vilnius: Lietuvos mokslas, 1999. 716 p. (in Lithuanian).

3. Gudkov, V. A.; Mirotin, L. B.; Velmozhin, A. V.; Shiriayev, S. A. Passenger carriage by motor vehicle (Пассажирские автомобильные перевозки). Moscow: Hot line - Telecom, 2004. 448 p. (in Russian).

4. Gorev, A. E. Freight transportation by motor vehicle (Грузовые автомобильные перевозки). Moscow: Academy, 2004. 288 p. (in Russian).

5. Jurkauskas, A.; Micevičienè, D.; Prunskienè J. The main principles of modelling the interaction between transport infrastructure development and economy. Transport, Vol 20, No 3, Vilnius: Technika, 2005, p. 117-122.

6. Išoraite, M. Evaluating efficiency and effectiveness in transport organizations. Transport, Vol 20, No 6, Vilnius: Technika, 2005, p. 240-247.

7. Kabashkin, I. The new European transport research activities. Transport, Vol 19, No 4, Vilnius: Technika, 2004, p. 191-194.

8. Paulauskas, V.; Paulauskas, D. The possibilities of port infrastructure investigations and development. Transport, Vol 18, No 5, Vilnius: Technika, 2003, p. 216-223.

9. Jarašūnienè, A. Analysis of the transport flows service time of the vehicles and the assessment of the indeterminacy of external impact. Transport, Vol 18, No 5, Vilnius: Technika, 2003, p. 198-201.

10. Romanov, A. N. Psychological problems in automobile transport (Автотранспортная психология). Moscow: Academy, 2002. 224 p. (in Russian).

11. Ertl, H. Higher Education in Germany: a case of "uneven" expansion? Higher Education Quarterly, Vol 59, No 3. Blackwell Publishing, 2005, p. 205-229.

12. Pérez-Foguet, A.; Oliete-Josa, S.; Saz-Carranza. Development Education and Engineering: A framework for incorporating reality of developing countries into engineering studies. International Journal of Sustainability in Higher Education, Vol 6, No 3. Emerald Group Publishing Limited, 2005, p. 278-303.

13. Biermans, M.; Jong U.; Leeuwen, M.; Roeleveld, J. Opting for science and technology. European Journal of Education, Vol 40, No 4. Blackwell Publishing, 2005, p. 433445.

14. Lumsden, M. A.; Bore, M.; Millar, K.; Jack, R.; Powis, D. Assessment of personal qualities in relation to admission to medical school. Medical Education, Vol 39, No 3. Blackwell Publishing, 2005, p. 258-265.

15. Richardson, W. Educational studies in the United Kingdom, 1940-2002. The British Journal of Educational Studies, Vol 50, No 1. Blackwell Publishing, 2002, p. 3-56.
16. Potter, J. New direction in student tutoring. Education + Training, Vol 39, No 1. MCB University Press, 1997. p. 24-29.

17. Garavan, T. N. Training, development, education and learning: different or the same? Journal of European Industrial Training, Vol 21, No 2. MCB University Press, 1997, p. 39-50.

18. Cannon, I. C. Higher education in Hong Kong. Higher Education Quarterly, Vol 51, No 4. Blackwell Publishing, 1997, p. 308-324.

19. Ineson, E. M. Selection for vocational courses - a consideration of the viewpoint of graduate employers. International Journal of Contemporary Hospitality Management, Vol 8, No 6. MCB University Press, 1996. p. 10-17.

20. Thomas, E. J. Developing continuing education and training in European universities. Journal of European Industrial Training, Vol 19, No 4. MCB University Press, 1995, p. 11-15.

21. Daniūnas, A.; Kliukas, R.; Plakys, V.; Prentkovskis, O.; Bernotiene, V. Get acquainted with the studies at Vilnius Gediminas Technical University (Sužinok apie studijas Vilniaus Gedimino technikos universitete). Vilnius: Technika, 2006. 164 p. (in Lithuanian).

22. Daniūnas, A.; Kliukas, R.; Prentkovskis, O. Progress of the country is caused by qualification of engineers and managers. In: Proceedings of XII international scientific and technical conference "Machine-Building and Technosphere of the XXI Century" held on 12-17 September 2005 in Sevastopol (Сборник трудов XII международной научно-технической конференции „Машиностроение и техносфера XXI века“, состоявшейся 12-17 сентября 2005 г. в городе Севастополе), Vol 1. Donetsk: DonNTU, 2005, p. 246253 (in Ukrainian).

23. Website of the Association of Lithuanian Higher Schools for Joint Students Admission - www.lamabpo.lt (in Lithuanian).

24. Open Information, Counselling and Guidance System (AIKOS) of Ministry of Education and Science of the Republic of Lithuania (Lietuvos Respublikos švietimo ir mokslo ministerijos Atvira informavimo, konsultavimo, orientavimo sistema AIKOS): www.aikos.smm.lt

25. Website of Vilnius Gediminas Technical University www.vgtu.lt

26. Website of Kaunas University of Technology - www.ktu.lt

27. Website of Klaipeda University - www.ku.lt

28. Daniūnas, A.; Kliukas, R; Prentkovskis, O. Joint admission to the Lithuanian universities. In: Proceedings of the first international scientific and practical conference "Scientific Potential of the World '2004" held on 1-15 November 2004. Vol 42: Strategic directions of education system reforming (Матеріали першої міжнародної науково-практичної конференції „Науковий потенціал СВІТУ'2004“ 1-15 листопада 2004 року. Том 42. Стратегічні напрями реформування системи освіти). Dnepropetrovsk: Science and education, 2004, p. 12-18 (in Russian).

29. Database of Joint Admission to Lithuanian higher schools (Priëmimo ị Lietuvos aukštąsias mokyklas informacijos sistema) (in Lithuanian). 